\title{
CRITÉRIOS DE ACESSO À EDUCAÇÃO INFANTIL NO BRASIL: ESTIGMATIZAÇÃO DA POBREZA, PRIVILÉGIO CORPORATIVO OU DISCRIMINAÇÃO POSITIVA?
}

\author{
CRITERIA TO THE ACCESS TO EARLY CHILDHOOD EDUCATION IN BRAZIL: \\ STIGMATIZATION OF POVERTY, CORPORATIVE PRIVILEGE OR \\ POSITIVE DISCRIMINATION?
}

\section{CRITERIOS PARA EL ACCESO A LA EDUCACIÓN PREESCOLAR EN BRASIL: ESTIGMATIZACIÓN DE LA POBREZA, PRIVILEGIO CORPORATIVO $O$ DISCRIMINACIÓN POSITIVA?}

Lívia Maria Fraga Vieira*

\begin{abstract}
Resumo: Por meio das políticas municipais de educação, o acesso à educação infantil tem se expandido no país nos últimos anos. Buscando estabelecer prioridades nas matrículas, observa-se a existência de procedimentos e critérios, no âmbito dessas políticas, para definir o público-alvo das instituições de educação infantil públicas. O que se problematiza, a partir de aportes históricos e da observação de políticas municipais atuais, é se a definição de critérios de elegibilidade para o acesso à oferta pública de educação infantil significou e significa estigmatização da pobreza, privilégio de grupos ou setores profissionais/ocupacionais ou política de discriminação positiva para setores historicamente excluídos. A legislação educacional de âmbito federal e estadual se constituiu na fonte privilegiada para este estudo. Foram analisadas as Constituições Federais, as leis nacionais da educação do período de 1937 a 1996 e a legislação do ensino do estado de Minas Gerais (1908 a 2000). Entre outras conclusões, verificou-se que a oferta pública tem sido historicamente definida como aquela voltada para crianças pobres, filhas de mães trabalhadoras ou que se encontram em situações diversas de vulnerabilidade social.
\end{abstract}

Palavras-chave: Educação Infantil. Critérios de matrícula. Políticas educacionais. Democratização do acesso.

\begin{abstract}
In recent years, in Brazil, the access to early childhood education has been expanded under municipal educational policies. In order to establish priority as for registration, procedures have been employed and criteria have been applied to define the audience for the public childhood schools. Considering historical aspects and observations of the current municipal policies, a discussion is intended in this article on whether the setting of criteria to the access to the childhood public education means and/or has meant a stigmatization of poverty, a privilege of professional/occupational groups or a positive discrimination for social groups historically excluded. The federal and/or state educational legislation is the main source analyzed in this research, which includes Federal Constitutions, education acts from 1937 to 1996, and state education laws of the state of Minas Gerais from 1908 to 2000. Among other conclusions, it was observed that the public offer has been historically defined as being
\end{abstract}

* Professora da Faculdade de Educação da Universidade Federal de Minas Gerais. Correio eletrônico: liviafraga@ globo.com. 
geared toward children which are poor, whose mothers work or that are in diverse situations of social vulnerability.

Keywords: Early Childhood education. Registration criteria. Educational policies. Democratizing access.

Resumen: En los últimos años, en Brasil, el acceso a la educación inicial se ha ampliado con las políticas educativas municipales. Con el fin de establecer prioridades en cuanto a registros, los procedimientos han sido utilizados y criterios han sido aplicados para definir la audiencia de las escuelas públicas de infancia. Teniendo en cuenta los aspectos históricos y las observaciones de las políticas municipales actuales, una discusión se pretende acerca de si el establecimiento de los criterios para el acceso a la educación pública de la niñez significa y/o ha supuesto una estigmatización de la pobreza, un privilegio de los grupos profesionales/ocupacionales o una discriminación positiva de los grupos sociales históricamente excluidos. La legislación educativa federal y/o estatal es la fuente principal analizada en esta investigación, que incluye Constituciones federales, los actos de educación de 1937-1996 y las leyes estatales de educación del estado de Minas Gerais de 1908-2000. Entre otras conclusiones, se observó que la oferta pública ha sido históricamente definida como siendo dirigida a los niños que son pobres, cuyas madres trabajan o que están en diversas situaciones de vulnerabilidad social.

Palabras clave: La Educación de la primera infancia. Criterios de registro. Políticas educativas. Acceso democratizador

\section{Introdução}

No Brasil, o direito constitucional da criança pequena a educação foi estabelecido em 1988, expressando anseio dos movimentos de luta por creches (guarderías) e pré-escolas (parvularios) surgidos no contexto de redemocratização da sociedade brasileira do final dos anos 1970. Uma intensa produção acadêmica sobre o tema, impulsionada pela movimentação social e pela articulação de pesquisadores e professores nas universidades e instituições de pesquisa, a partir do início dos anos 1980, contribuiu fortemente para que as definições legais incluíssem a criança de 0 a 6 anos de idade como sujeito de direito a educação. Os municípios foram especialmente responsabilizados pela oferta da educação infantil, definida como primeira etapa da Educação Básica ${ }^{\text {. }}$

1. No Brasil, a educação escolar está estruturada em dois grandes níveis de ensino: educação básica e educação superior. A educação básica está configurada em três etapas: educação infantil, para crianças de 0 a 5 anos de idade; ensino fundamental, com duração de nove anos, cobrindo a faixa etária de 6 a 14 anos; e ensino médio, para jovens de 15 a 17 anos.
A oferta de educação infantil hoje no Brasil integra a política educacional. É entendida como a frequência regular a uma instituição escolar exterior ao domicílio doméstico, por crianças que, até recentemente, não estavam submetidas a obrigatoriedade escolar. É que a Emenda Constitucional n. 59, de 11 de novembro de 2009, instituiu a obrigatoriedade escolar para pessoas de 4 a 17 anos de idade. Com isso, o último segmento da Educação Infantil, que a legislação educacional denomina de pré-escola, ganha o estatuto de educação obrigatória, de frequência compulsiva. Outra mudança recente é quanto à faixa etária abrangida pela educação infantil, que passou a ser a de 0 a 5 anos de idade, a partir da aprovação da Emenda Constitucional n. 53, de 19 de dezembro de 2006. Com isso, a idade de ingresso no Ensino Fundamental, ampliado para nove anos de duração por legislação específica, passou a ser a de 6 anos.

O acesso à Educação Infantil no Brasil é, no entanto, ainda muito desigual. As disparidades em relação a faixa etária, etnia/cor, localização (urbano/rural), renda familiar e 
escolaridade dos pais/responsáveis, sobretudo da mãe, vêm sendo recorrentemente apontadas nos estudos sobre a oferta de educação infantil no Brasil. Tais disparidades concorrem para penalizar as crianças mais novas, as mais pobres, as que habitam áreas rurais e as não brancas.

Os dados da Pesquisa Nacional de Amostra de Domicílios - PNAD (IBGE, 2011) mostram que a taxa de escolarização das crianças na faixa de idade de 0 a 3 anos ainda é baixa, tendo atingido a cobertura de $23 \%$ em 2011. Verificamos, por outro lado, que está cada vez mais generalizado o acesso à pré-escola para crianças a partir de 4 anos de idade, tendo atingido nesse mesmo ano a taxa de escolarização de $81,7 \%$. Chama assim atenção a enorme disparidade de acesso em relação à faixa etária.

Disparidades significativas são também observadas quando levamos em conta a renda familiar da criança e a localização - região e urbano/rural. De acordo com o estudo de Rosemberg e Artes (2012), baseado no Censo Demográfico-2010, a taxa de frequência total a creche ou escola por crianças cujo rendimento familiar per capita equivale ao primeiro quartil de renda (o mais baixo) é de $45,1 \%$, e a das crianças situadas no quartil mais rico é de $63,2 \%$, ou seja com uma diferença de 18,1 pontos percentuais.

Ainda segundo o Censo Demográfico de 2010, apenas 6,3\% das crianças entre 0 e 2 anos foram atendidas nas áreas rurais, enquanto na área urbana 16,7\% estão na creche. Quase 54\% das crianças de 3 anos frequentou creche urbana, ao passo que nas creches rurais esse percentual foi de apenas $28,5 \%$. $\mathrm{Na}$ faixa de 4 e 5 anos de idade, $67,6 \%$ das crianças são atendidas na área rural, enquanto na área urbana são 83\%.

Rosemberg e Artes (2012) constataram, por outro lado, que o acesso a creches e pré-escolas segundo as variáveis sexo e cor/raça não apresentou diferenças significativas.

Algumas pesquisas mostram ainda que, para os mais pobres e não brancos, o acesso não significa necessariamente usufruir de um atendimento de qualidade, o que vem sendo definido pelo fato de os serviços, obedecendo o marco legal, contarem com profissionais com formação adequada e valorização, acesso a espaços amplos e confortáveis, gratuidade, proposta pedagógica e participação das famílias (CAMPOS, 2006).

Por meio das políticas municipais de educação, o acesso à Educação Infantil tem se expandido no país, contemplando aproximadamente 7,3 milhões de crianças de 0 até 6 anos (MEC/INEP, 2012), de um universo de 19,6 milhões de habitantes nessa faixa etária. Buscando estabelecer prioridades nas matrículas, observa-se a existência de procedimentos e critérios, no âmbito dessas políticas, para definir o público-alvo das instituições de educação infantil públicas. Com efeito, estudos históricos que analisam a legislação do ensino confirmam essa regularidade no tratamento da oferta pública de creches, jardins de infâncias, escolas infantis ou centros/unidades de educação infantil. A oferta pública tem sido historicamente definida como aquela voltada para crianças pobres, filhas de mães trabalhadoras ou que se encontram em situações diversas de vulnerabilidade social.

O que queremos problematizar, a partir de aportes históricos e da observação de políticas municipais atuais, é se a definição de critérios de elegibilidade para o acesso à oferta pública de educação infantil significou e significa estigmatização da pobreza, privilégio de grupos ou setores profissionais/ ocupacionais ou política de discriminação 
positiva $^{2}$. Ou seja, o estabelecimento de escalas de prioridades reitera desigualdades, estigmatizando crianças pobres e favorecendo setores profissionais específicos ou promove inclusão e oportunidades para a infância e a família das classes populares?

Buscando contribuir para a resposta a essas questões, nós utilizamos um estudo de longa perspectiva histórica em que destacamos os critérios para regular a matrícula de crianças nas escolas públicas de educação infantil no Brasil (VIEIRA, 2006). A legislação educacional de âmbito federal e estadual constituiu-se na fonte privilegiada. Foram analisadas as Constituições Federais, as leis nacionais da educação do período de 1937 a 1996 e a legislação do ensino do estado de Minas Gerais (1908 a 2000), situado na região Sudeste do país. Trata-se de um conjunto de leis e atos normativos produzido ao longo do século XX.

\section{Educação Infantil na legislação nacio- nal do ensino brasileiro: 1937 a 1996}

A Educação Infantil não foi esquecida pelos legisladores e, mesmo de forma econômica, está presente na legislação geral do ensino no Brasil produzida ao longo do século XX. No entanto, o tema esteve ausente das Constituições Federais até 1988. Foram proclamadas sete Constituições Nacionais, sendo a primeira ainda no Império, em 1824

2. Discriminar positivamente é tratar diferentemente aqueles que são diferentes, dando mais aos que têm menos. É conceito ambíguo, abarcando dois sentidos: positivo, para os que dela se beneficiam, e negativa, para os que estão de fora. Implica focalização. É comumente vinculada à ideia de cotas. O objetivo é minimizar a desigualdade entre os grupos sociais por meio de um tratamento diferencial direcionado aos grupos mais vulneráveis do ponto de vista social e econômico, de modo que tais grupos consigam superar suas carências em relação ao restante da sociedade (CALVÈS, 2008).
(COSTA, 2002). Assim, pela primeira vez, uma Constituição brasileira fará referência aos direitos específicos das crianças, não circunscritos ao âmbito do Direito da Família, estabelecendo $o$ atendimento em creche $e$ pré-escola como direito da criança de 0 a 6 anos e como dever do Estado (CAMPOS, ROSEMBERG \& FERREIRA, 1989). O direito dos trabalhadores - homens e mulheres, urbanos e rurais - à assistência gratuita aos filhos e dependentes em creches e pré-escolas também foi assegurado.

As legislações complementares que se seguiram - o Estatuto da Criança e do Adolescente (ECA), de 1990, a Lei Orgânica da Assistência Social (LOAS), de 1993, e a Lei de Diretrizes e Bases da Educação Nacional (LDBEN), de 1996 - reiteraram esses direitos.

A Educação Infantil é evidenciada na estrutura administrativa do Ministério da Educação apenas em 1974, quando se cria a Coordenação Geral de Educação PréEscolar (COEPRE). Coincide com a presença do tema nos Planos Setoriais de Educação do período. Mais tarde, em 1992, transforma-se em Coordenação Geral de Educação Infantil (COEDI), subordinada atualmente à Secretaria de Educação Básica (SEB).

Antes desse período, as creches, como também as escolas maternais e os jardins de infância, faziam parte do programa do Departamento Nacional da Criança (DNCr), criado em 1940 no âmbito do Ministério da Educação e Saúde, para ser o supremo órgão responsável pela proteção à infância e à maternidade. Após 1953, com o desmembramento do referido Ministério, o DNCr permaneceu na estrutura do Ministério da Saúde, mas continuou a se ocupar da educação infantil, por meio de orientações, divulgação de manuais e realização de inquéritos sobre a situação da infância e das instituições 
médico-sociais que dela se ocupavam. Em 1970, foi substituído pela Coordenação de Proteção Materno-Infantil do mesmo Ministério. O DNCr era um órgão normativo que tinha o papel de difusor dos preceitos da puericultura e de um modelo de implantação de serviços de "proteção à maternidade e à infância" nos municípios e estados, que se baseava na ação de médicos e outros notáveis, e suas respectivas esposas, para a criação das Associações de Proteção à Maternidade e à Infância (APMI), obras de particulares, que concorriam às subvenções dos governos federal e estaduais (VIEIRA, 1986, 1988; PEREIRA, 1999; SOUSA, 2000).

A legislação infraconstitucional comentada foi a seguinte:

- Plano Nacional de Educação, projeto elaborado em 1937 pelo Conselho Nacional de Educação;

- Lei de Diretrizes e Bases da Educação Nacional (LDBEN), de 1961;

- Lei Federal no 5.692, de 1971, que instituiu o ensino de primeiro e segundo graus;

- Lei de Diretrizes e Bases da Educação Nacional, de 1996.

\section{7: Educação Infantil no Plano de Educação Nacional}

A partir da Constituição de 1934, começa-se a estabelecer a competência privativa da União para traçar as diretrizes da educação nacional. No lugar de uma lei de diretrizes, competiria à União fixar um plano nacional de educação, compreensivo do ensino de todos os graus e ramos, comuns e especializados, atribuindo-se a tarefa ao Conselho Nacional de Educação. Esse é o motivo de ressaltarmos os aspectos relativos à educação da criança de 0 a 6 anos constantes do projeto desse plano nacional. Encaminhado à Presidência da República em 18 de maio de 1937, o projeto não chegou sequer a entrar em discussão no Congresso Nacional, em virtude das mudanças políticas acontecidas no país quando se instaurou a ditadura do "Estado Novo".

O Plano apresentado era minucioso, tratando da educação comum, média e superior, em seus diferentes cursos e respectivos conteúdos. A Educação Infantil foi objeto de uma seção específica tratando do ensino comum, que compreendia os ciclos pré-primário, primário e secundário, sendo "anterior a qualquer especialização, destinado a favorecer e a dirigir o desenvolvimento da infância e da adolescência, em tudo quanto diga respeito à formação geral do homem e do cidadão...” (RBEP, 1949, p. 211).

Dispondo sobre o ensino pré-primário em dois artigos, buscou-se conceituar e apontar responsabilidades em relação a sua oferta:

Art. 36 - O ensino pré-primário compreende a educação que for ministrada em jardins de infância ou escolas-infantis, a crianças de 4 a 6 anos de idade, com o objetivo de adaptá-las ao meio social, pela inculcação de hábitos sadios, desenvolvimento das capacidades de expressão e coordenação sensorial-motriz.

Art. 37 - O ensino pré-primário compete à família, a instituições particulares e, subsidiariamente, a instituições para êsse fim criadas pelos poderes públicos.

Parágrafo único. As instituições de ensino pré-primário oficiais serão abertas nos bairros de habitação operária e deverão receber, de preferência, as crianças órfãs de mãe e cuja mãe trabalha fora do lar. (RBEP, 1949, p. 212).

A responsabilidade pela educação da criança pequena, na faixa de idade de 4 a 6 
anos, é claramente nomeada: em primeiro lugar, a família; em segundo, as instituições particulares; e, por último, os poderes públicos. O Estado entraria assim de forma subsidiária e apenas para atender à criança morando em bairros operários ou vivendo situações excepcionais: quando separadas da mãe, seja pela orfandade ou pela necessidade de trabalhar fora do lar. Para isso, seriam criadas as instituições de ensino pré-primário oficiais.

Preocupou-se o Plano em definir e conceituar o ensino pré-primário, bem como em determinar os objetivos a serem alcançados. A ação pública ficou estabelecida para responder a situações especiais.

“Adaptação", "inculcação" são termos que definem os objetivos e que nos evocam uma concepção vertical de socialização infantil e de uma criança a ser moldada, devir-adulto formado nos bons hábitos e com capacidades de expressão e coordenação sensório-motriz.

\section{1: a primeira Lei de Diretrizes e Bases da Educação Nacional e a Educação Infantil}

Na Exposição de Motivos e no Relatório Geral da Comissão que elaborou o primeiro projeto da LDBEN, em 1948, enviado ao Congresso Nacional, a educação pré-primária, um item específico, figurava com a seguinte justificativa:

A comissão designada pelo "Board of Education" da Inglaterra, em 1908, para estudar o problema da educação pré-escolar, concluiu, após haver visitado jardins de infância e escolas maternais da própria Inglaterra, e também da França, da Bélgica, da Suíça e da Alemanha, que, onde quer que o lar ofereça condições satisfatórias, é ele o lugar indicado para a educação das crianças ainda imaturas para a escola primária.
Infelizmente nem todos os lares oferecem “condições satisfatórias”. Circunstâncias diversas, tais como exiguidade da habitação, o caso do filho único, o de órfãos, o de mães doentes e principalmente o de mães forçadas a trabalhar fora de casa, reclamam a cooperação daqueles educandários. Deve-se igualmente reconhecer que um valiosíssimo papel assimilador podem eles desempenhar, ensinando o idioma nacional aos pré-escolares em cujas famílias só se fale língua estrangeira. Isto por si só justifica a criação de jardins de infância nos núcleos de imigração. (RBEP, 1949, p.63) (grifos nossos)

No mesmo Relatório, no item denominado “O Direito a Educação", também se fez referência à educação pré-primária no tema "a educação e a família”, com a seguinte redação:

A execução da tarefa educativa constituirá "nos anos antes do uso da razão" um dever e um privilégio da família: "a educação será dada no lar...”. Objetou-se contra isto, nos princípios deste século, que "a família conserva, em nove casos sobre dez, o espírito de etapas inferiores de cultura”, e que "os que não foram educados não podem educar” (Muller-Lyer, apud Almeida Junior, 1949). Afirmou-se, consequentemente, a conveniência de se entregar desde cedo a criação e a educação infantil (como na República de Platão e nos primórdios do comunismo russo) a berçários e a estabelecimentos pré-escolares. Mas a experiência desacreditou esse sucedâneo, mostrando que, a despeito de suas deficiências, continua a família, em relação aos primeiros anos de vida, a ser a instituição mais qualificada para educar. E mais ainda o será quando as novas gerações de pais, preparadas para essa missão desde a escola primária, assumirem, em futuro próximo, o respectivo posto no lar. (idem, p. 58) 
As escolas maternais e os jardins de infância, reconhecidos como educandários que oferecem educação pré-escolar, deviam se destinar a crianças em contextos e situações muito especiais: as que viviam em situação de pobreza, evidenciada pela exiguidade da habitação; aquelas cujas mães eram "forçadas" a trabalhar, ou que advinham de lares pobres, vivendo na penúria e na doença. Era, sobremaneira, um recurso ligado a pobreza. As instituições infantis se justificariam assim pela "falta” de família. É a concepção que parece imperar nesse momento nas justificações oficiais.

Com efeito, a defesa de instituições de Educação Infantil no Brasil desse período era realizada segundo a concepção dominante de “mal necessário". Nessa visão, a origem de instituições tipo creches, mas também jardins de infância e escolas maternais, estaria fundada no imperativo do trabalho feminino fora do domicílio. E o trabalho feminino era visto como um mal, um problema, um constrangimento, a evidência de um desajuste na manutenção da família. A análise do discurso e das ações do Departamento Nacional da Criança - DNCr (1940-1970) sobre as instituições infantis revelou tais concepções (VIEIRA, 1988).

Essas concepções não existiam apenas no Brasil. O relatório internacional citado mostra que essas ideias eram compartilhadas pelas autoridades políticas e educacionais dos países europeus, que difundiram os jardins de infância e as escolas maternais para outros continentes desde o final do século XIX.

O Relatório Geral não apontava, no entanto, apenas a falta da família. Reconhecia a importância da convivência da criança com seus pares, para seu desenvolvimento, ao defender as instituições pré-escolares para famílias com apenas um filho, e também o papel assimilador das instituições pré-escolares para filhos de imigrantes: para aprendizagem da outra língua e a inserção na cultura.

O enunciado para a educação pré-primária é transcrito a seguir:

Título V - Da educação pré-primária

Art. 14 - As instituições pré-primárias têm por objetivo prestar assistência às crianças de menos de sete anos, e proporcionar-lhes educação adequada.

Art. 15 - As empresas que tenham a seu serviço mães de crianças em idade inferior a sete anos serão estimuladas a organizar e a manter, por si ou em cooperação com os poderes públicos, instituições pré-primárias para crianças. (idem p. 65) (grifos nossos)

Definiam-se os objetivos das instituições pré-primárias: assistir e educar. Sem nomear as instituições pré-primárias, visto que a nomenclatura, as normas para a instalação e o funcionamento ficariam a cargo dos poderes públicos locais, vemos explicitada, mais uma vez, sua relação com o trabalho feminino. A iniciativa de organização e manutenção deveria ser das empresas que tivessem a seu serviço mães de crianças menores de 7 anos. Essas empresas seriam estimuladas, por sujeito não nomeado, a prestar assistência e educação, por si ou em cooperação com os setores públicos. ${ }^{3}$

A Lei de Diretrizes e Bases da Educação Nacional foi somente aprovada em dezembro de 1961, após onze anos de tramitação. A Educação Infantil, nomeada educação pré-primária, terá redação similar

3. A indicação para a instalação de berçários, destinados às crianças até 6 meses de idade, visando permitir a amamentação, em empresas que empregavam mais de 100 mulheres, constou da Consolidação das Leis do Trabalho (CLT), legislação promulgada em 1942, no que se referiu à proteção do trabalho feminino. 
à proposta do anteprojeto, em capítulo específico do Título VI, Da educação de Grau Primário. Enuncia-se primeiro a definição de educação pré-primária: “a educação pré-primária destina-se aos menores até sete anos, e será ministrada em escolas maternais ou jardins de infância". E, em segundo lugar, alude-se aos estímulos que as empresas, empregando mães de menores de 7 anos, receberão para organizar e manter instituições de educação pré-primária, "por iniciativa própria ou em cooperação com os poderes públicos". Persiste a ausência do sujeito que estimularia as empresas nessa situação.

Assim, o aprovado em 1961 em relação a educação pré-primária parece guardar coerência com as posições do referido relatório internacional, datado de 1908, e citado no primeiro projeto de LDBEN brasileira de 1948, apesar das significativas mudanças sociais e econômicas sofridas pela sociedade brasileira, provavelmente reposicionando a demanda e a necessidade das instituições pré-primárias.

\section{1: a reforma do Ensino de Primeiro e Segundo Graus na Lei $n^{\circ}$ 5.692/1971}

O anteprojeto de Lei Federal $n^{\circ}$ 5.692, de agosto de 1971, é um texto conciso, no qual se buscou justificar os grandes eixos sobre os quais deveria se assentar a organização do ensino brasileiro. Foi elaborado por grupo de trabalho constituído pelo Ministro da Educação e Cultura para propor a reforma do ensino primário, ginasial e secundário, tendo prazo de 60 dias, a contar da instalação, para apresentar seus estudos e projetos.

O documento, contendo sete partes, reconhecia a diversidade de situações encontradas no território brasileiro dada pela realidade difusa dos municípios.
Tendo em vista a realidade do ensino "que já não se adequava mais às necessidades do desenvolvimento econômico e emprestava à educação uma estrutura tradicional e segmentada", sugeria-se a divisão do ensino em $1^{\circ}$ e $2^{\circ}$ graus, precedendo o de $3^{\circ}$ grau ou superior. O primeiro correspondia a uma escolarização de oito anos letivos, integrando verticalmente o primário e ginasial, e o segundo, de três ou quatro anos.

A educação pré-escolar mereceu atenção no item que tratou do financiamento, quando se falou sobre uma forma indireta de acrescer recursos para a educação mediante o ensino ministrado pela iniciativa privada e às suas expensas, que eram os cursos de aprendizagem e qualificação ministrados pela indústria e pelo comércio. A educação pré-escolar foi mencionada segundo as concepções abaixo transcritas:

Na mesma linha inclui-se a organização de serviços educativos que precedem o ensino regular de $1^{\circ}$ grau. $O$ trabalho feminino, sobretudo nos centros maiores, equipara-se em todos os campos ao masculino, assim em qualidade como em quantidade de horas. Isso impõe à mulher uma constante ausência do lar, gerando problemas de toda sorte para a educação dos filhos. A solução para que se caminha, e que em alguns países já se fez rotina, é a manutenção de creches, escolas maternais e jardins de infância próximos aos locais de trabalho. Trata-se de um interesse das próprias empresas, para maior eficiência dos seus servidores, mas não seria ainda o caso de sobrecarregá-las com o ônus exclusivo que daí resulta. Por isso mesmo, no anteprojeto, colocamos a matéria em termos de estímulo por parte dos sistemas e previmos que os serviços montados nesse pressuposto poderão receber cooperação financeira e técnica do Poder Público. Quanto à oportunidade do dispositivo, lembramos que uma boa educação 
na primeira infância é condição de êxito na escolarização regular e no ajustamento mesmo da personalidade (Relatório..., 1971, p. 163).

Esse enunciado relacionava a educação "que antecede o ensino regular de primeiro grau" com as demandas do trabalho feminino e com os benefícios de uma boa educação na primeira infância. Tratar-seia muito mais de uma política do trabalho, de proteção ao trabalho feminino, pois a criança a ser atendida era o filho da mulher trabalhadora, e os serviços deveriam ficar a cargo dos empregadores. Diferentemente da LDBEN de 1961, enunciava-se quem deveria estimular as empresas: os sistemas de ensino.

Em 1971, na Lei nº 5.692, a educação pré-escolar consta do capítulo referente ao ensino de primeiro grau:

Art. 17 - $\mathrm{O}$ ensino de $1^{\circ}$ grau destina-se à formação da criança e do pré-adolescente, variando em conteúdo segundo as fases do desenvolvimento dos alunos.

Art. 18 - O ensino de $1^{\circ}$ grau terá duração de oito anos letivos e compreenderá, anualmente, pelo menos 720 horas de atividades.

Art. 19 - Para o ingresso no ensino de $1^{\circ}$ grau, deverá ter o aluno a idade mínima de sete anos.

$\S 1^{\circ}$ - As normas de cada sistema disporão sobre a possibilidade de ingresso no ensino de primeiro grau de alunos com menos de sete anos de idade.

$\S 2^{\circ}$ - Os sistemas de ensino velarão para que as crianças de idade inferior a sete anos recebam conveniente educação em escolas maternais, jardins de infância $e$ instituições equivalentes.

Art. 20-O ensino de $1^{\circ}$ grau será obrigatório de 7 aos 14 anos, cabendo aos Municípios promover, anualmente, o levantamento da população que alcance a idade escolar e proceder a chamada da matrícula.

Parágrafo único - Nos Estados, no Distrito Federal, nos Territórios e nos Municípios, deverá a administração do ensino fiscalizar o cumprimento da obrigatoriedade escolar e incentivar a frequência dos alunos. (grifos nossos)

Outra referência foi ainda encontrada no capítulo sobre o financiamento: “os sistemas de ensino estimularão as empresas que tenham em seus serviços mães de menores de sete anos a organizar e manter, diretamente ou em cooperação, inclusive com o Poder Público, educação que preceda o ensino de $1^{\circ}$ grau".

Inferida, mas não nomeada, a Educação Infantil recebeu tratamento muito limitado. Apesar de não ter sido completamente esquecida, não há referência a quaisquer dispositivos de vigilância ou de responsabilização de qualquer esfera pública sobre a "conveniente educação que a criança menor de sete anos” deveria receber em instituições que são especificadas.

Avança em relação ao texto da LDBEN, de 1961, pois indica os sistemas de ensino como o sujeito que estimulará as empresas a manter e organizar "educação que preceda o ensino de $1^{\circ}$ grau”. A leitura desses textos nos mostra que as responsabilidades públicas neste período da nossa história não estão definidas. Educação Infantil é colocada como sendo da esfera privada, seja da família, dos empregadores, da filantropia ou da iniciativa particular lucrativa, tradicionalmente responsabilizadas ou reclamadas para assistir e educar a pequena infância.

Além disso, se mantém a justificativa de criação de tais instituições para responder às necessidades das mães que trabalham fora do lar, a quem se destinaria a manutenção e a organização de educação precedendo o 
ensino obrigatório. Sem omitir que "uma boa educação na primeira infância é condição de êxito na escolarização regular e no ajustamento mesmo da personalidade" (grifo nosso), a argumentação apresentada privilegiou assim as consequências do trabalho feminino para a organização da família e a criação de filhos pequenos.

A imagem da criança que emana desse texto faz continuidade com os textos legislativos anteriores. Preparar a criança para ser aluno exitoso na escola primária regular e ajustar, moldar, adaptar sua personalidade ao meio social, nos remete à imagem de uma criança objeto, tábula rasa, folha em branco.

Sem novidades quanto à concepção da criança e ao papel - proeminente - da família e da iniciativa privada e ao papel - retraído e subsidiário - do Estado, a reforma do ensino de $1^{\circ}$ e $2^{\circ}$ graus de 1971 parece ter introduzido de forma clara a possibilidade da antecipação da escolaridade obrigatória, com a redação do parágrafo $1^{\circ}$ do artigo 19 . Isso suscitará consultas ao Conselho Federal de Educação, vindas dos sistemas de ensino estaduais, e posicionamentos sobre os custos financeiros dessa antecipação.

A omissão da lei nacional quanto à educação da criança de 0 a 6 anos apareceu como incompatível com a nova situação social brasileira, devido à urbanização crescente, às modificações na estrutura familiar e às novas demandas sociais e políticas que a década de 1970 inaugurava. Com as novas interpretações da pobreza que as agências multilaterais (Unesco, Unicef) divulgavam, essa quase ausência parece ter motivado o posicionamento do órgão normativo da educação sobre os instrumentos e as estratégias, visando: primeiro, situar o lugar dessa educação nos sistemas de ensino e nas políticas sociais; segundo, regular uma oferta mais abrangente de educação pré-escolar.
O Conselho Federal de Educação (CFE) assume então um papel propositivo, coincidente com as concepções (e as movimentações) que começam a vigorar no âmbito do Ministério da Educação e de outros órgãos do poder executivo federal no período. É notável a profícua produção sobre o tema que se abriu no âmbito do CFE no período de 1974 a 1981.

\section{O Conselho Federal de Educação e a educação da criança de 0 a 6 anos: 1974 a 1981}

Para Petitat (1994), o clima dos anos 1950 ajuda a compreender as orientações das pesquisas empíricas em sociologia da educação, que teriam contribuído para moldar novas representações das desigualdades escolares e de suas causas: início da Guerra Fria entre os países do Leste e do Ocidente, que também é guerra econômica, e retorno da ideia de que a educação é fator de prosperidade e de poder. Houve também rápido e vigoroso impulso econômico no pós-guerra. O progresso tecnológico é visto como principal fonte de transformações sociais, demandando mais gente formada para responder às necessidades da sociedade tecnológica. Consequentemente, a educação, em especial a formação técnica e científica, é concebida como mola propulsora de desenvolvimento econômico e poderio político. $\mathrm{O}$ autor mostra que neste ambiente surgem os estudos destinados a esclarecer os poderes públicos acerca dos melhores momentos para as reformas escolares, como também a sondar a "reserva de talentos" e a avaliar o papel do "capital humano" no crescimento econômico.

De maneira bastante sintética, o autor aponta que toda uma literatura sociológica apresentando o insucesso escolar como produto de carências culturais e linguísticas dos 
meios mais modestos trouxe uma teorização às práticas de educação compensatória.

No Brasil, as justificativas enfatizadas nos anos 1970 para a expansão da pré-escola visando atingir crianças dos meios desfavorecidos ancoravam-se naquela literatura e nas experiências norte-americanas de educação compensatória, que interpretava a pobreza como questão pessoal e, assim, justificava investimentos na educação da primeira infância (PENN, 2002). A produção sobre o assunto foi relativamente abundante, tanto no que se refere às proposições quanto às críticas que se fizeram acompanhar. Pesquisas e estudos foram produzidos no âmbito das universidades e centros de pesquisa, defendendo ou combatendo as propostas compensatórias. ${ }^{4}$

A educação pré-escolar passou a ser vista como urgência, em face do pequeno número de instituições pré-escolares existentes no país - os denominados jardins de infância e escolas maternais, que atendiam a crianças das classes médias e altas. Contavam-se que $60 \%$ do atendimento existente, já muito pequeno, era devido à iniciativa particular; 10 milhões de crianças de 4 a 6 anos, outros milhões na faixa de 0 a 4 anos, sem atendimento, são números que exemplificavam o déficit, considerado assustador, sobretudo porque os pobres eram os mais prejudicados, justamente os que chegavam à escola sem qualquer experiência escolar institucional prévia e ampliavam as estatísticas do fracasso escolar.

Como financiar essa expansão da pré-escola para os pobres? Quais modelos de oferta foram apregoados?

Após a aprovação da Lei Federal $n^{\circ}$ 5.692, de 1971, o Conselho Federal de

4. Veja-se a respeito, por exemplo: Patto, 1973; Poppovic, 1975; Souza, 1979; Didonet, 1981; Ferrari, 1982; Santos, 1982; Saraiva, 1982; Kramer, 1984; Campos, 1979; Franco, 1989.
Educação iniciou uma série de manifestações sobre a educação pré-escolar, defendendo sua expansão de acordo com alguns modelos de atendimento considerados possíveis frente aos constrangimentos financeiros para alcançar os objetivos prioritários de oferecer a educação obrigatória a todos.

Os Pareceres e as Indicações do Conselho Federal de Educação sobre a educação que antecede o ensino de primeiro grau, produzidos ao longo da segunda metade dos anos 1970 e início de 1980, têm o mérito de apontar a lacuna na legislação educacional. E talvez pelas próprias debilidades do ensino obrigatório, recomendaram-se a pré-escola para as massas, apregoando-se soluções para fora do sistema escolar, e a adoção de modelos ditos "não-convencionais", "de amplo atendimento e baixo custo", "com a participação ativa da comunidade", "integrando cuidados de educação, alimentação e saúde", chamados de educação compensatória (INEP, 1982). Desnutrição, privação cultural, pobreza, analfabetismo dos pais, trabalho extradoméstico da mãe exigiriam respostas variadas, vindas de diferentes setores das políticas públicas, as quais passam a reclamar a participação das comunidades demandatárias. O contexto brasileiro era o do início da crise do regime militar, e o Governo Geisel tinha sua proposta de distensão lenta, segura e gradual. No plano das políticas sociais, presencia-se a criação de programas educacionais e assistenciais que visavam atingir os "bolsões de pobreza", verdadeiro manancial de ressentimentos, possíveis fontes de "desequilíbrios sociais" (VIEIRA, 1986; ROSEMBERG, 1992, 1997).

No período de 1974 a 1981, foram produzidos sete pareceres e duas indicações sobre o tema. A primeira indicação e os pareceres que lhe seguiram agendam a educação pré-escolar no sistema de ensino brasileiro, defendendo a perspectiva compensatória,

Olhar de professor, Ponta Grossa, 16(1): 49-74, 2013. Disponível em <http://www.uepg.br/olhardeprofessor> 
pautada nas teorias da privação cultural: reconhecem as necessidades da criança, a necessidade de contemplar a formação de professores e a urgência da ampliação do acesso como fator de oportunação escolar, visando sobretudo "combater o fracasso escolar".

Os últimos pareceres e orientações já indicam claramente as estratégias de expansão, por meio da utilização de modelos ditos não convencionais, reconhecendo os limites do financiamento e propondo fórmulas "baratas” para o atendimento da infância pobre.

As críticas mostravam os limites de uma "pré-escola pobre" na missão de "salvar a escola"... também pobre. A concepção da infância pobre como um conjunto de carências e faltas, e não como conceito positivo, afirmativo em suas diversidades e desigualdades, mostrou-se excludente. O movimento crítico buscou afirmar o direito a educação com boa qualidade.

As proposições predominantes no CFE, também presentes nos planos setoriais de educação e nos documentos ministeriais, parecem reforçar o lugar da educação pré-escolar como sobra, como apêndice de política educacional que visaria universalizar o ensino fundamental, num contexto de embates pela valorização da educação pública.

A perspectiva de "mal necessário", subjacente à legislação educacional de 1937 a 1971 para a educação da criança de 0 a 6 anos, foi substituída por uma visão de "educação compensatória”, lugar de combater carências/pobreza, valorizando o popular e o comunitário nos programas e planos governamentais. Esse ideário sintetiza o eixo das políticas de educação infantil durante os governos militares, com o respaldo das recomendações e assessorias da Unesco e do Unicef (ROSEMBERG, 1992).

\section{A Educação Infantil na legislação brasileira contemporânea}

A década de 1980, considerada perdida nos cânones econômicos, foi muito instigante do ponto de vista da participação e da democracia.

A criança de 0 a 6 anos emerge como um novo sujeito de direitos a educação, direitos que devem ser assegurados por instituições e deveres constituídos no âmbito dos sistemas escolares. Isso tem a ver com as novas concepções da primeira infância, que se expressam na produção do campo universitário, respaldadas pelas mudanças no perfil sócio-demográfico da sociedade brasileira e pela ação do movimento social, que acabam por instaurar também novas exigências de qualificação profissional no campo da educação da primeira infância. Assim, o pessoal diretamente responsável pela criança deve ter qualificação e formação profissional docente em nível de ensino superior, sendo admitida formação mínima de nível médio, oferecida em curso de formação de magistério.

Duas ideias motrizes estiveram presentes na constituição da Educação Infantil como direito a educação, como nos lembra Rosemberg (2002):

a) a busca na educação infantil de igualdade de oportunidades para as crianças, por meio de políticas e ações para proteger e dar efetividade aos direitos e melhorar a qualidade de vida, não reproduzindo ou reforçando desigualdades econômicas, raciais e de gênero;

b) a adoção de uma concepção ampla de educação, pautada na percepção de criança como ser ativo, competente, agente, produtor de cultura, pleno de possibilidades atuais, e não apenas futuras - criança como ator social, e não 
como objeto de socialização e de práticas de escolarização disciplinadoras.

Esse olhar sobre a criança que se foi construindo no Brasil relaciona-se com o movimento científico observado mundialmente de desnaturalização da infância, que a reconhece como construção social. Não é mais visto simplesmente como um momento precursor, mas como componente da cultura e da sociedade: ator social, e não simplesmente como ser em devir, um devir a ser moldado. Nesse sentido, a educação infantil é tributária das novas concepções da infância trazidas pelos estudos da história e sociologia da infância e da psicologia (SIROTA, 2001). Trabalha com premissas cada vez mais difundidas, mas não necessariamente hegemônicas.

Esse movimento científico não é independente do debate social que ocorreu em torno dos direitos da criança, como nos alerta Sirota (2001). Assinalamos que o Brasil é signatário da Carta Internacional dos Direitos da Criança e da Convenção Internacional de 1989. E, desde 1990, aprovou o Estatuto da Criança e do Adolescente (Lei Federal $n^{\circ} 8.069,1990$ ), que simboliza o acesso da criança e do adolescente ao estatuto de sujeito e à dignidade da pessoa.

Em relação à legislação educacional contemporânea, pode-se concluir brevemente que, além da criança de 0 a 6 anos ser reconhecida como sujeito de direitos a educação, rompe-se, no plano da lei, com a tradição de atribuir à família a responsabilidade exclusiva pela socialização e pela educação de crianças nessa faixa etária. E também já não se concebe, como antes, como um serviço a ser organizado exclusivamente pela iniciativa privada, quando participava o governo apenas como ator subsidiário.

\section{Legislação educacional de Minas Gerais: critérios de matrícula na educação infantil}

A legislação educacional do governo estadual de Minas Gerais, produzida ao longo do século XX, reflete as concepções sobre a criança e sua educação encontradas na legislação nacional, o que se relaciona com as ideias dominantes sobre a família, o Estado e as políticas sociais em contextos históricos específicos. De forma descentralizada, aos estados brasileiros competiria a regulamentação da oferta e da organização do ensino.

Nós dividimos a legislação estadual em cinco grandes períodos que acompanham de perto a legislação da educação nacional. O Quadro $n^{\circ} 1$ sintetiza, nos períodos referidos, os temas tratados e as categorias/estabelecimentos de ensino encontrados.

Destacamos, em seguida, os critérios de matrícula nos jardins de infância e escolas maternais constantes na legislação analisada, que configuram as prioridades de atendimento do setor público.

\section{Período 1908-1930}

O primeiro jardim de infância público foi instituído em 1908, decorrência da reforma republicana do ensino primário do Governo João Pinheiro, iniciada em 1906 em Minas Gerais. Em seguida, no ano de 1911, foi publicado o programa de ensino das escolas infantis.

No "Regulamento do Ensino Primário", de 1924, as escolas infantis foram divididas em duas categorias: jardins de infância e escolas maternais. No parágrafo único do artigo 121 constava: "as primeiras serão instaladas onde houver grande densidade de população, e as segundas poderão sê-lo nos grandes centros fabris e industriais". 
Quadro $n^{\circ} 1$. Corpo jurídico da educação infantil do Governo do estado de Minas Gerais: temas e denominações - 1908 a 2000

\begin{tabular}{|c|c|c|c|}
\hline $\begin{array}{l}\text { Anos/ } \\
\text { períodos }\end{array}$ & Corpo jurídico & Temas & $\begin{array}{c}\text { Denominação dos } \\
\text { estabelecimentos e } \\
\text { categorias de ensino }\end{array}$ \\
\hline $1908-1930$ & $\begin{array}{l}\text { Decretos (regulamentos e } \\
\text { programas de ensino) }\end{array}$ & $\begin{array}{l}\text { Funcionamento dos estabelecimentos } \\
\text { Programa de ensino } \\
\text { Objetivos } \\
\text { Pessoal/atribuições } \\
\text { Definição de público-alvo }\end{array}$ & $\begin{array}{l}\text { Escola infantil } \\
\text { Jardim de infância } \\
\text { Escola maternal }\end{array}$ \\
\hline $1930-1961$ & $\begin{array}{l}\text { Decretos (códigos de } \\
\text { ensino) }\end{array}$ & $\begin{array}{l}\text { Definição de categoria de ensino } \\
\text { Objetivos }\end{array}$ & $\begin{array}{l}\text { Ensino pré-primário } \\
\text { Jardim de infância }\end{array}$ \\
\hline $1962-1971$ & Decretos e Resoluções & $\begin{array}{l}\text { Objetivos } \\
\text { Definição de público-alvo } \\
\text { Definição de normas para implantação } \\
\text { Normas de autorização de funcionamento }\end{array}$ & $\begin{array}{l}\text { Ensino pré-primário } \\
\text { Jardim de infância } \\
\text { Curso pré-primário } \\
\text { Classes pré-primárias }\end{array}$ \\
\hline 1973-1988 & Resoluções, Instruções & $\begin{array}{l}\text { Objetivos } \\
\text { Orientações pedagógicas } \\
\text { Definição de público-alvo } \\
\text { Definição de normas para a expansão do } \\
\text { atendimento } \\
\text { Novos programas de expansão } \\
\text { Normas de autorização de funcionamento }\end{array}$ & Educação pré-escolar \\
\hline $1988-2000$ & $\begin{array}{l}\text { Resoluções, Instruções, } \\
\text { Circulares, Informações }\end{array}$ & $\begin{array}{l}\text { Objetivos } \\
\text { Orientações pedagógicas pessoal/formação } \\
\text { Programa de formação } \\
\text { Definição de normas para não expansão } \\
\text { Regulação da oferta do estado e dos municí- } \\
\text { pios (municipalização) } \\
\text { Normas de autorização de funcionamento }\end{array}$ & $\begin{array}{l}\text { Educação pré-escolar } \\
\text { Educação infantil }\end{array}$ \\
\hline
\end{tabular}

Fonte: Legislação educacional do Estado de Minas Gerais, 1908 a 2000 (elaboração da autora)

Em 1927, nova reforma de ensino, conhecida como Reforma Francisco Campos, também fará referência às escolas infantis, conforme "Regulamento do Ensino Primário".

Definiu-se que as escolas maternais se destinariam "à educação de crianças de 4 a 6 anos, filhas de operários, devendo, para esse fim, funcionar de 7 horas da manhã às 5 da tarde" (art. 248). Diferentemente, os jardins de infância receberiam as crianças apenas por quatro horas diárias.

Instituíram-se também critérios para a matrícula desde 1911. A partir de 1924, foram especificados conforme se aplicassem ao jardim de infância ou à escola maternal. No Quadro $n^{\circ} 2$, pode-se verificar como isso foi tratado em cada um dos Regulamentos. 
Quadro $n^{\circ}$ 2. Critérios de matrícula na educação infantil constantes dos Regulamentos de Ensino de 1911, 1924 e 1927 - Minas Gerais

\begin{tabular}{|c|c|c|c|c|}
\hline \multirow{2}{*}{$\begin{array}{l}\text { Regulamentos } \\
\text { de Ensino }\end{array}$} & \multicolumn{4}{|c|}{ Critérios de matrícula } \\
\hline & Idades & Sexo & Outros & Preferências \\
\hline $\begin{array}{l}1911 \\
\text { Decreto } 3.191\end{array}$ & $\begin{array}{l}\text { - Idade escolar: } 7 \text { a } 16 \text { anos; } \\
\text { - Infantil: vedada a matrícula de } \\
\text { menores de } 4 \text { e a maiores de } 7 \\
\text { anos. }\end{array}$ & & & \\
\hline $\begin{array}{l}1924 \\
\text { Decreto } 6.655\end{array}$ & $\begin{array}{l}\text { • nos jardins de infância: crianças } \\
\text { maiores de } 4 \text { e menores de } 7 \\
\text { anos; } \\
\text { • nas escolas maternais seriam } \\
\text { admitidas tantas crianças quanto } \\
\text { o prédio pudesse acomodar, sendo } \\
\text { vetada a matrícula de crianças } \\
\text { menores de } 3 \text { e maiores de } 6 \text { anos. }\end{array}$ & $\begin{array}{l}\text { Um e } \\
\text { outro }\end{array}$ & $\begin{array}{l}\text { • não sofrer moléstia } \\
\text { contagiosa incurável ou } \\
\text { repugnante; } \\
\text { • ser vacinada contra a } \\
\text { varíola. }\end{array}$ & $\begin{array}{l}\text { • os filhos de ope- } \\
\text { rárias; } \\
\text { • os órfãos de mãe; } \\
\text { • os filhos de profes- } \\
\text { soras. }\end{array}$ \\
\hline $\begin{array}{l}1927 \\
\text { Decreto } \\
7.970-\mathrm{A}\end{array}$ & $\begin{array}{l}\text { - Idade escolar obrigatória: } 7 \text { a } \\
14 \text { anos; } \\
\text { • No jardim de infância: } 4 \text { a } 6 \\
\text { anos; } \\
\text { • Nas escolas maternais: } 4 \text { a } 6 \\
\text { anos. }\end{array}$ & & $\begin{array}{l}\text { • prova de vacinação } \\
\text { antivariólica; } \\
\text { • não sofrer nenhuma } \\
\text { das moléstias ou defeitos } \\
\text { enumerados no art. } 101 \text {, } \\
\S 1^{\circ} \text {. }\end{array}$ & $\begin{array}{l}\text { - nas escolas } \\
\text { maternais, filhos de } \\
\text { operários. }\end{array}$ \\
\hline
\end{tabular}

Fonte: Regulamentos de Ensino do Estado de Minas Gerais, 1911, 1924 e 1927. (elaboração da autora)

No Regulamento de 1927 estabelecia-se ainda que "o ensino dos Jardins de Infância é facultativo e somente gratuito para os alunos notoriamente pobres, pagando os demais uma taxa de matrícula de $50 \$ 000$ por ano, que poderá ser satisfeita em 5 prestações iguais, de dois em dois meses". Nas escolas maternais, garantia-se a gratuidade para todos.

Por ser facultativa a matrícula, e não ser para todos, a ação pública carecia de definir prioridades, “focalizando” a criança e a família a serem preferencialmente atendidas: filhas de operários, habitando zonas urbanas densas, órfãs de mães e filhas de professoras. Estabeleceu-se assim um sistema moderno republicano, que, além da escola primária obrigatória, respondeu pela educação facultativa para crianças menores de 7 anos de idade. Chama atenção a presença dos filhos de professoras no rol das preferências do atendimento, o que pode indicar uma demanda corporativa específica que se vai configurando a partir do próprio sistema de ensino.

\section{Período 1931-1963}

O “Código do Ensino Primário”, de 1950, não fez mais que consolidar as leis e decretos do ensino primário que vigoraram nos anos 1930 e 1940. Introduz-se a nomenclatura “ensino pré-primário”.

Os critérios de matrícula para as escolas infantis se mantiveram inalterados, bem como as regras do funcionamento. Nos jardins de infância, continuava facultativa a matrícula, e gratuita somente para os “alunos notoriamente pobres”. Como nas escolas maternais teriam matrícula os filhos dos 
operários, dispensava-se qualquer pagamento de taxas, sendo portanto facultativa e gratuita a matrícula.

Mudanças mais significativas na organização do ensino primário e pré-primário só seriam visualizadas no Código do Ensino Primário, editado pelo governo mineiro em 1962.

Em relação aos períodos anteriores, na década de 1960, os jardins de infância cresceram consideravelmente no estado de Minas Gerais, instituídos por meio dos decretos governamentais. Esse crescimento ocorreu em todo o país. Deu-se ênfase, por meio de iniciativas diversas, à formação de professoras para atuarem em classes pré-primárias.

Neste Código, os estabelecimentos de ensino - entre os quais, o jardim de infância - foram classificados segundo sua organização e localização. Constituindo categoria de ensino, a educação pré-primária seria ministrada às crianças maiores de 4 anos.

O critério básico de matrícula no curso pré-primário era a idade da criança, compreendida entre 4 e 6 anos. Seriam preferidas as crianças residentes no setor escolar do estabelecimento, sendo vedado o acesso aos que apresentassem defeitos físicos ou psíquicos impeditivos da frequentar a escola e aos portadores de doença contagiosa ou repulsiva. Ressaltava-se que, sempre que possível, os mesmos seriam matriculados em estabelecimentos ou classes de ensino especializados.

\section{1 - Administração Escolar do Esta- do: definindo critérios corporativos de matrícula na pré-escola}

Em janeiro de 1971, antes da aprovação da nova estrutura do ensino de primeiro e segundo graus, foi editado um ordenamento da instrução no estado, a Resolução $n^{\circ}$ 51, que tratou da administração escolar estadual.

De acordo com essa nova Resolução, ficou definido que o "curso pré-primário" seria constituído pelos jardins de infância e pelas classes pré-primárias. Seria admitida a matrícula de crianças de 4 a 6 anos (jardim de infância) e de 6 anos (pré-primária), tendo preferência os candidatos residentes no setor escolar do estabelecimento.

Pela primeira vez a legislação definiria uma série de critérios para as situações em que o número de vagas não fosse suficiente para atender a todos os candidatos. Evidenciando-se os critérios corporativos, que expressam a escala de incorporação das diferentes categorias ocupacionais nos benefícios do sistema de previdência social brasileiro desde a década de 1930, estabeleceu-se a seguinte escala de prioridades:

$$
\begin{aligned}
& \text { I - filhos de expedicionários }{ }^{5} \text {; } \\
& \text { II - filhos de operários; } \\
& \text { III - filhos de funcionários [públicos]; } \\
& \text { IV - filhos de comerciários; } \\
& \text { V - filhos de bancários; } \\
& \text { VI - filhos de industriários; } \\
& \text { VII - filhos de profissionais liberais; } \\
& \text { VIII - filhos de comerciantes; } \\
& \text { IX - filhos de industriais e outros de cate- } \\
& \text { gorias semelhantes. }
\end{aligned}
$$

Observando-se a escala acima, quando o número de candidatos enquadrados no item a ser atendido fosse superior ao número

\footnotetext{
5. Expedicionário foi a pessoa/homem convocada para participar dos combates, ao lado dos países do bloco aliado, na Segunda Guerra Mundial. Essa convocação ocorreu a partir de 1942 e motivou a criação da primeira grande instituição de assistência social brasileira, a Legião Brasileira de Assistência (LBA), pela senhora Darcy Vargas, esposa do presidente Getúlio Vargas, visando atender às famílias dos convocados (VIEIRA, 1986).
} 
de vagas, a escolha devia ser feita por meio de sorteio. Para o cumprimento das prioridades, deveria o pai ou responsável apresentar, no ato da matrícula, o documento comprobatório, a critério da autoridade escolar responsável.

Santos (1979) usou o conceito de cidadania regulada para caracterizar o modelo de proteção social brasileiro, que se expandiu sobretudo a partir dos anos 1930. Era a condição de ser possuidor de carteira de trabalho assinada que definia o acesso do "cidadão" aos benefícios do sistema de proteção social. Essa inclusão resultava de critérios corporativos, dados pela maior capacidade de pressão das categorias profissionais que sobressaíam no cenário das pressões e lutas sociais. O estatuto da cidadania era a inserção no mundo do trabalho regulado, do trabalho formal urbano. O contexto era o de um Estado populista baseado em pacto corporativo com sindicatos de categorias urbanas.

A presença dos expedicionários no cume da lista de prioridades parece indicar que o Estado deveria atender, em primeiro lugar, às famílias, alvo da assistência social, em virtude das consequências da ausência do homem provedor convocado para a Segunda Guerra Mundial. Além disso, o "expedicionário" ganhou o significado de herói da nação, reverenciado e credor de dívida nacional.

\section{Período de 1973 a 1988: pressão da demanda, regulação da oferta}

A partir de 1971, os sistemas de ensino dos estados brasileiros deveriam progressivamente adequar a organização e o funcionamento das escolas à nova legislação aprovada em agosto daquele ano.

No lugar de decretos regulamentadores, o governo estadual buscava estabelecer as normas e os critérios orientadores do "ensino pré-escolar" e de "primeiro grau", editando Resoluções no início ou no final de cada ano. Foram analisadas seis Resoluções relativas aos anos de 1973, 1974, 1976, 1977, 1978 e 1984.

Destaca-se também nessas Resoluções a presença de exigências que passaram a compor a legislação educacional mineira, e que se acrescentavam a cada ano, regulando a instalação do ensino pré-escolar. Pressupõese uma demanda persistente que certamente será aparente junto às escolas públicas, estaduais ou municipais, manifestada pelas famílias e pelos políticos locais às professoras, às diretoras, às Delegacias Regionais de Ensino, às Prefeituras Municipais (prefeitos e órgãos/setores competentes). A leitura da lei permite supor que a "sociedade" exerce pressão para a abertura de classes pré-escolares.

Apesar da manutenção das denominações das instituições pré-escolares - as escolas maternais e os jardins de infância -, novos termos são introduzidos, tais como classes pré-escolares, classes pré-escolares de demonstração (laboratórios do Estado), classes anexas às creches, educação pré-escolar, coexistindo com os anteriores até a Resolução editada em 1977.

Observamos o estabelecimento de critérios para a matrícula e de condicionantes para a manutenção e a ampliação de escolas ou classes pré-escolares no sistema de ensino.

No Quadro $n^{\circ}$ 3, buscou-se sintetizar os critérios definidores de prioridades de atendimento à demanda por educação pré-escolar presentes nas citadas Resoluções do período.

Olhar de professor, Ponta Grossa, 16(1): 49-74, 2013. Disponível em <http://www.uepg.br/olhardeprofessor> 
Quadro n. 3. Critérios de matrícula constantes das Resoluções que regulam a organização do ensino na Secretaria de Estado da Educação (SEE/MG) - 1973 a 1984

\begin{tabular}{|c|c|c|}
\hline & & \\
\hline $\begin{array}{l}\text { O seguinte criterı: } \\
0 \% \text { das vagas preenchidas me- } \\
\text { te comprovação de maturidade } \\
\text { andidato; } \\
\text { 0\% das vagas destinadas à ma- } \\
\text { la de alunos carentes, obedecida } \\
\text { dem decrescida de carência de } \\
\text { rsos. } \\
\text { no de 1974, poderão ser man- } \\
\text { as classes de } 3^{\circ} \text { período, a fim } \\
\text { arantir a continuidade de estu- } \\
\text { aos alunos que já pertencem ao } \\
\text { elecimento. (art. } 41 \text { ) } \\
\text { permitida a matrícula de can- } \\
\text { to de } 4,5 \text { e } 6 \text { anos, nas classes } \\
\text { escolares de demonstração (la- } \\
\text { tórios do Estado) e nas classes } \\
\text { as às creches. (art. } 42 \text { ) } \\
\text { - Terão prioridade para a } \\
\text { ícula nas classes pré-escolares } \\
\text { emonstração: } \\
\text { lho de ex-combatente; } \\
\text { ilho de elemento do magistério } \\
\text { ede estadual, residente no zone- } \\
\text { hto; } \\
\text { filho de professor, de aluno e de } \\
\text { ionário da unidade; } \\
\text { irmão de aluno matriculado no } \\
\text { eelecimento, naquele nível de } \\
\text { to. } \\
\text { - As demais vagas serão } \\
\text { nchidas de acordo com critério } \\
\text { ulado no § } 2^{\circ} \text { do artigo anterior } \\
\text { - }\end{array}$ & $\begin{array}{l}\text { Atendimento à demanda de acordo } \\
\text { com o seguinte critério: } \\
\text { I - } 60 \% \text { das vagas destinadas à ma- } \\
\text { trícula de alunos carentes, obedecida } \\
\text { a ordem decrescente de carência de } \\
\text { recursos. } \\
\text { II - } 40 \% \text { das vagas preenchidas } \\
\text { obedecida a ordem decrescente dos } \\
\text { resultados obtidos em teste de ma- } \\
\text { turidade. } \\
\text { Fica assegurado o direito à matrí- } \\
\text { cula, aos filhos de expedicionários, } \\
\text { de professores e especialistas de } \\
\text { educação da rede pública estadual, } \\
\text { independentemente dos critérios es- } \\
\text { tabelecidos no artigo. (art. } 39 \text { ) } \\
\text { Será permitida a matrícula de can- } \\
\text { didato de } 4,5 \text { e } 6 \text { anos, nas classes } \\
\text { pré-escolares de demonstração (la- } \\
\text { boratórios do Estado) e nas classes } \\
\text { anexas às creches. (art. } 40 \text { ) } \\
\S \quad 1^{\circ} \text { - Terão prioridade para a } \\
\text { matrícula nas classes pré-escolares } \\
\text { de demonstração: } \\
\text { I - filho de ex-combatente, de pro- } \\
\text { fessor e especialista de educação da } \\
\text { rede pública estadual; } \\
\text { II - filho de aluno e de funcionário } \\
\text { da unidade; } \\
\text { III - irmão de aluno, matriculado no } \\
\text { estabelecimento, naquele nível de } \\
\text { ensino. } \\
\S 2^{\circ} \text { - As demais vagas serão } \\
\text { preenchidas de acordo com critério } \\
\text { estipulado no § } 2^{\circ} \text { do artigo anterior } \\
\text { - art. } 39 .\end{array}$ & $\begin{array}{l}\text { Atendimento à demanda segundo } \\
\text { o zoneamento, quando a medida se } \\
\text { impuser, com os seguintes critérios } \\
\text { de prioridade: } \\
\text { I - filho de ex-combatente, professor } \\
\text { ou especialista de educação da rede } \\
\text { pública estadual; } \\
\text { II - filho de funcionário da unidade; } \\
\text { III - ordem decrescente de carência } \\
\text { de recursos da família do candidato. } \\
\text { (art. } 36) \\
\text { Será permitida a matrícula de can- } \\
\text { didato de } 4,5 \text { e } 6 \text { anos, nas classes } \\
\text { pré-escolares de demonstração (la- } \\
\text { boratórios do Estado) e nas classes } \\
\text { anexas às creches e nos Jardins de } \\
\text { Infância. (art. } 37) \\
\S 1^{\circ} \text { - Terá prioridade para a } \\
\text { matrícula: } \\
\text { I - filho de ex-combatente, de pro- } \\
\text { fessor e especialista de educação da } \\
\text { rede pública estadual; } \\
\text { II - filho de aluno e de funcionário } \\
\text { da unidade; } \\
\text { III - irmão de aluno, matriculado no } \\
\text { estabelecimento, naquele nível de } \\
\text { ensino. } \\
\S 2^{\circ} \text { - As demais vagas serão } \\
\text { preenchidas de acordo com critério } \\
\text { estipulado no } \S 3^{\circ} \text { do art. } 36 \text {. } \\
\S 5^{\circ} \text { - O atendimento nas classes } \\
\text { pré-escolares não garantirá a } \\
\text { matrícula na } 1^{a} \text { série do mesmo } \\
\text { estabelecimento, ficando o aluno } \\
\text { sujeito o zoneamento escolar para o } \\
1^{\circ} \text { grau. }\end{array}$ \\
\hline
\end{tabular}

Fonte: Resoluções da SEE/MG. Em 1977, permaneceu em vigor o que se estabeleceu na Resolução nº 1.728/1976.* Entende-se por zoneamento escolar a área territorial fixada para atuação de cada escola oficial, considerando sua capacidade de atendimento. 
Quadro n. 3. Critérios de matrícula constantes das Resoluções que regulam a organização do ensino na Secretaria de Estado da Educação (SEE/MG) - 1973 a 1984 (continuação)

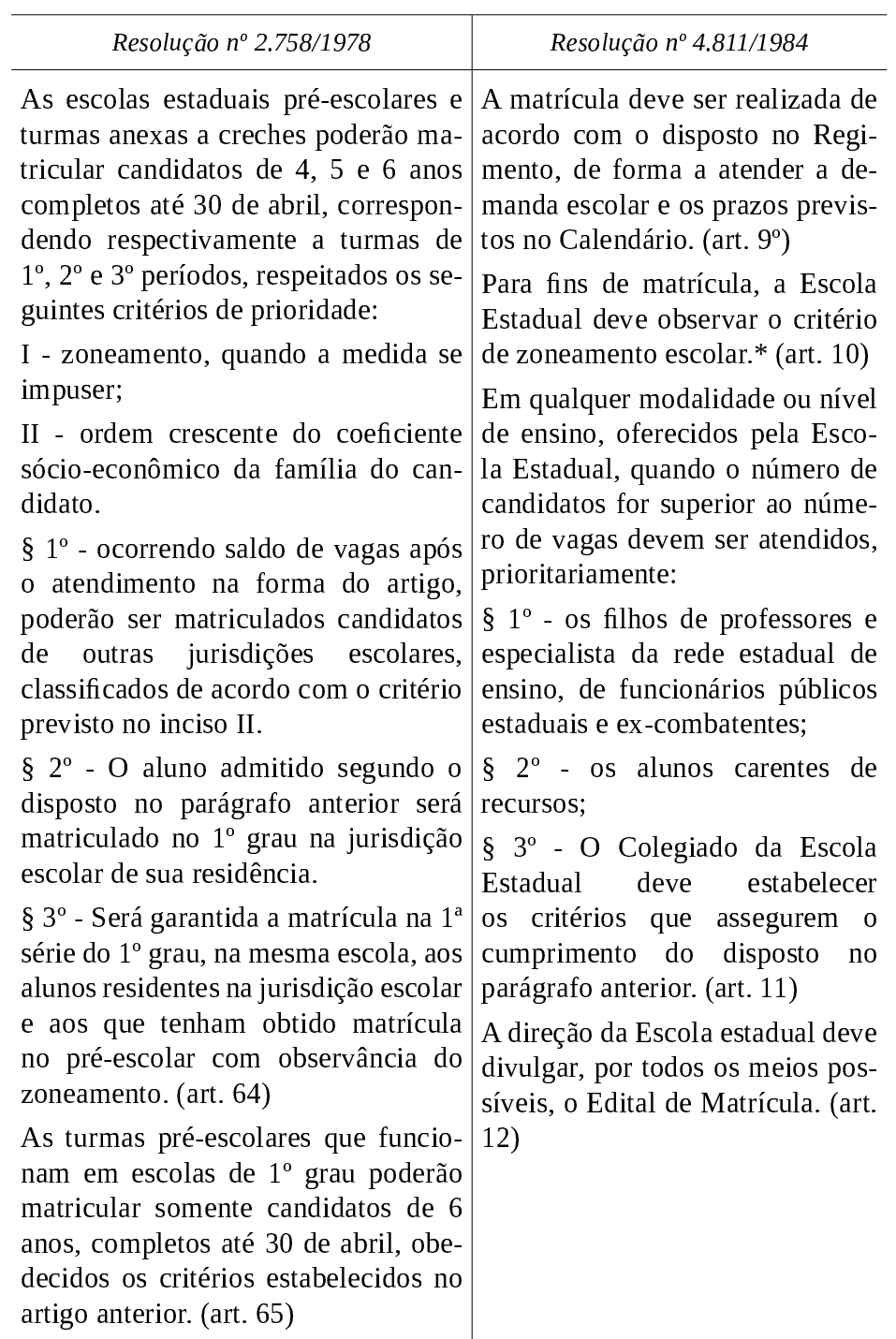

Em todas as Resoluções, foi estabelecida a não gratuidade do ensino de $2^{\circ}$ grau, pré-escolar e cursos específicos dos conservatórios estaduais de música, ficando os alunos matriculados sujeitos a pagamento de anuidades.

A partir de 1973, novas matrículas nos jardins de infância e classes pré-escolares só poderiam ser oferecidas para crianças de 6 anos de idade e desde que não acarretassem prejuízo ao atendimento da faixa etária de 7 a 14 anos no ensino de $1^{\circ}$ grau. Dizia-se também, na Resolução de 1973, que novas matrículas não poderiam resultar em aumento de turmas nas escolas estaduais.

Além disso, verificou-se que a Resolução se preocupou em definir o que era “aluno carente de recursos": referia-se ao 
candidato cujo índice socioeconômico fosse igual ou inferior a 3 , resultado de cálculo de fórmula complexa.

\section{Após 1988: municipalização da educa- ção pré-escolar}

Após a promulgação da Constituição Federal de 1988, observa-se um intenso reordenamento das redes de ensino, decorrência das competências federativas mais claramente definidas: ensino fundamental compartilhado entre o município e o estado, educação infantil atribuída ao município, ensino médio ao estado. Com isso, instaurou-se um acentuado e acelerado processo de municipalização das matrículas estaduais da pré-escola e das primeiras quatro séries do ensino fundamental.

As Resoluções do período entre 1991 e 1995, que organizam o funcionamento escolar, sempre fundamentadas sobre o princípio da gestão democrática, anunciam os deveres do Estado em relação a educação, reiterando o que estava consagrado na Constituição Federal. A Constituição Estadual de Minas Gerais, de 1989, apresentou enunciado distinto, estabelecendo que "o dever do Estado com a Educação será efetivado mediante a oferta de: [...] atendimento ao pré-escolar, desde que devidamente atendida a demanda de Ensino Fundamental”.

Enunciava-se reiteradamente, nas Resoluções citadas, que a educação pré-escolar nas escolas da rede estadual atenderia prioritariamente a crianças de 6 anos.

Definiram-se as "modalidades" de oferta da educação pré-escolar na rede estadual, sendo ministrada em: escola estadual de educação pré-escolar, escola estadual de ensino fundamental que mantenha turma de educação pré-escolar e creche que ministre a educação pré-escolar para crianças de 4 a 6 anos.
No período, o único critério definido para as matrículas foi o zoneamento escolar. Mais tarde, acrescentou-se: "vedado o exame de seleção de candidatos". Por zoneamento escolar, entendia-se a área territorial fixada para atuação de cada escola oficial, considerando-se sua capacidade de atendimento.

\section{Considerações finais}

O panorama apresentado pela análise da legislação educacional evidencia pelo menos duas regularidades na edificação da educação da criança pequena nos sistemas de ensino. Ocupando lugar secundário e como política contingente, a oferta pública constituiu-se e ampliou-se sob condições ou reservas, quando não implicava prejuízo do ensino primário ou fundamental obrigatório. Essa oferta esteve sempre destinada a determinadas crianças: pobres, órfãs ou filhas de mães operárias; filhas de professoras e funcionários públicos; filhas de expedicionários e categorias ocupacionais específicas.

A presença continuada da definição de prioridades e critérios de inclusão para a matrícula de crianças nas escolas infantis, também chamadas de jardins de infância, instituições pré-primárias ou pré-escolares, acompanha a constituição do Estado Social no Brasil, com a construção dos direitos de cidadania, ao longo do século $\mathrm{XX}$ (CARVALHO, 2003). As escalas de prioridades consideraram inicialmente os filhos de mães trabalhadoras ou os órfãos de mãe. Mesmo reconhecendo o valor educativo da educação infantil, o sentido da creche e das instituições pré-primárias como sendo instituições que se prestavam a ação benemerente do empresariado e da filantropia, e voltadas preferencialmente a pobres e famílias “desorganizadas” pelo trabalho feminino na esfera 
pública, parece ter contribuído para estigmatizar a creche, as crianças das classes populares e as famílias de mães trabalhadoras.

Sem abandonar o critério dado pelo trabalho feminino fora do domicílio, foi observada a existência de critérios corporativos somados à eleição de índices relativos a renda mensal familiar e outras situações que caracterizam vulnerabilidade social. Esses últimos prevalecem, nos dias atuais, nos procedimentos de escolha de crianças inscritas para obtenção de vaga em unidade de educação pública de municípios (VILANOVA, 2010). As mudanças sociais e demográficas das últimas décadas, o aumento da inserção da mulher no mercado de trabalho e as novas expectativas em relação à educação das crianças pequenas nas sociedades contemporâneas estão na base das pressões mais fortes junto ao poder público por aumento da oferta de educação infantil.

Os critérios corporativos foram mencionados pela primeira vez em 1911. Tornaram-se marcantes nos anos 1970, persistindo quando não existiam definições propositivas das esferas federais de governo em relação ao tema. É sobretudo no final dessa década que, nos governos da ditadura militar, se observa extremo processo de centralização de recursos financeiros e de decisões sobre programas, inclusive nas áreas sociais. Implantaram-se ações fortemente indutoras, pois eram financiadas diretamente pelo órgão federal. Tratava-se de apresentar aos estados e municípios possibilidades de oferta de educação pré-escolar, incentivando e divulgando experiências por meio de encontros, seminários e algumas publicações. Os Ministros de Educação passaram a se manifestar publicamente sobre o assunto. Sem deixar de figurar, os critérios corporativos começaram a coexistir com os critérios de renda, medidos por "índices de carência socioeconômica”. Buscou-se dirigir a pré-escola estadual para os mais pobres, conforme definições legais. De uma demanda corporativa, a legislação estadual - tomando-se as novas diretrizes para o pré-escolar preconizadas pelo Ministério da Educação e outros órgãos federais com seus programas específicos - parece falar de um outro tipo de demanda, agora focada nas crianças das classes populares, que apresentariam quadro de privações diversas. Convivia-se também com a manifestação de uma demanda mais generalizada, aberta pelo feminismo e pelos movimentos populares que começavam a organizar os serviços eles mesmos, as creches e pré-escolas comunitárias, constituindo um "lócus profissional", ocupacional de mulheres, sem as concomitantes qualificação e escolarização para o trabalho.

Esses novos elementos - defesa de uma pré-escola de massa, baseada em modelo dito "não convencional"; crise da ditadura militar e o surgimento de novos modelos de serviços sociais que enfatizam a "participação comunitária"; a ampliação e a diversificação da demanda - contribuíram para a reestruturação dos critérios de oferta, fazendo conviver no período os critérios corporativistas com outros calcados em índices de "pobreza", além de outro universal baseado no zoneamento escolar.

No entanto, chama atenção a presença reiterada de critério que favorecia a matrícula de filho(s) de professores ou especialistas de educação da rede pública estadual, bem como do funcionalismo público, mesmo quando se enfatizou a observância do critério do zoneamento escolar. Em 1984, a citação da categoria "docente" aparece antes da categoria "filho de ex-combatente ou expedicionário", diferentemente das Resoluções antes publicadas. Não estaria configurado um privilégio? Privilégio que se instituiu em função de uma demanda que se organiza a partir do próprio sistema de ensino? Não 
teríamos assim uma das motivações para fazer avançar a educação pré-escolar, para crescer as matrículas? Pode-se sugerir que a demanda por educação infantil é erigida também no interior mesmo dos sistemas escolares, na medida em que as vagas ofertadas, em número insuficiente no período, são disputadas pelos trabalhadores aí engajados.

Nas décadas de 1990 e 2000, de acordo com as características nacionais, o que se observou foi uma crescente municipalização da pré-escola, seja pela transferência das matrículas [e escolas] das redes estaduais para os municípios ou pela ampliação da demanda e a crescente responsabilização da esfera local de governo no plano da legislação. Amplia-se também a oferta pública de creches. Tornou-se, então, dominante a participação dos municípios na oferta de educação infantil, coexistindo com a nova conceituação como primeira etapa da educação básica e como direito social da criança. Os déficits de cobertura ainda ensejam a adoção de critérios de inclusão das crianças, em que preponderam a renda familiar e o trabalho da mãe no conjunto de situações que definem situações de vulnerabilidade social: habitação em áreas de risco, desnutrição da criança, crianças sob medidas de proteção (submetidas a violência e negligência familiar), crianças com necessidades especiais, crianças cujas famílias se encontram no cadastro de um amplo programa federal de transferência de renda com condicionalidades, chamado de "Bolsa Família"'. Assim, os critérios definidos no âmbito da Política Nacional de Assistência Social serão usados na política de educação para definir e constituir o público-alvo das

6. Vinculado ao Ministério do Desenvolvimento Social e Combate à Fome (MDSCF), abrange mais de 11 milhões de famílias em todos os municípios brasileiros. Em Belo Horizonte, são atendidas aproximadamente 64 mil famílias. Disponível em http://www.mds.gov. br/bolsafamilia/lista-de-beneficios. unidades ou escolas de educação infantil. É o que se observou na política municipal de Belo Horizonte, capital de Minas Gerais (VILANOVA, 2010). Tais medidas, acompanhadas de complexos procedimentos de inscrição e escolha das famílias, criam um campo de tensão na política educacional, tendo em vista que o direito a educação é universal. Ao mesmo tempo, baseiam-se no reconhecimento de que a distribuição dos serviços na cidade é desigual e de que existe um déficit de cobertura, com taxas de escolarização ainda insuficientes para as crianças pobres e não brancas. De acordo com conclusões do estudo de Vilanova (2010), a oferta pública destinada prioritariamente a crianças que se enquadram nos critérios de elegibilidade da política de assistência social só se constituirá em discriminação positiva se for temporária, se diversificar o público-alvo incluindo outros demandatários, se existir meta de universalização e se os serviços se estruturarem de acordo com padrões de qualidade já definidos no âmbito da Política Nacional de Educação.

\section{Referências}

CALVÈS, G. La discrimination positive. 2. ed. Paris: PUF, 2008.

CAMPOS, M. M. Assistência ao pré-escolar: uma abordagem crítica. Cadernos de Pesquisa, São Paulo, n. 28, p. 53-61, mar. 1979.

; ROSEMBERG, F.; FERREIRA, I. A Constituição de 1988 e a educação de crianças pequenas. São Paulo: FDE, 1989.

CAMPOS, M. et al. Qualidade da educação infantil brasileira: alguns resultados de pesquisa. Cadernos de Pesquisa, São Paulo, v. 36, n. 127 p. 87-128, jan./abr. 2006.

CARVALHO, J. M. Cidadania no Brasil: o longo caminho. Rio de Janeiro: Civilização Brasileira, 2003. 
COSTA, M. A educação nas Constituições do Brasil: dados e direções. Rio de Janeiro: DP\&A Editora, 2002.

DIDONET, V. Pré-escolar: um atendimento urgente. Revista Educação, Ministério da Educação, Brasília, p. 38-40, out./dez. 1981.

FERRARI, A. R. Pré-escola para salvar a escola?. Educação e Sociedade. São Paulo, v. 4, n. 12, p. 29-37, set. 1982.

FRANCO, M. A. C. Lidando pobremente com a pobreza: análise de uma tendência no atendimento a crianças "carentes" de 0 a 6 anos de idade. In: ROSEMBERG, F. (Org.). Creche. São Paulo: Cortez, 1989. p. 179215.

KRAMER, Sônia. A política do pré-escolar no Brasil: a arte do disfarce. Rio de Janeiro: Achiamé, 1984.

PATTO, M. H. S. Privação cultural e educação pré-primária. Rio de Janeiro: José Olympio, 1973.

PENN, H. Primeira infância: a visão do Banco Mundial. Cadernos de Pesquisa, São Paulo, n. 115, p. 7-24, mar. 2002.

PEREIRA, A. R. A criança no Estado Novo: uma leitura de longa duração. Revista Brasileira de História, São Paulo, v. 19, n. 38, p. 165-198, 1999.

PETITAT, A. Produção da escola/produção da sociedade: análise sócio-histórica de alguns momentos decisivos da evolução escolar do ocidente. Porto Alegre: Artes Médicas, 1994. 268 p.

POPPOVIC, A. M. et al. Marginalização cultural: subsídios para um currículo pré-escolar. Cadernos de Pesquisa, São Paulo, n. 14, p. 7-73, set. 1975.

ROSEMBERG, F. A educação pré-escolar brasileira nos governos militares. Cadernos de Pesquisa, São Paulo, n. 82, p. 21-30, ago. 1992.
A LBA, o Projeto Casulo e a Doutrina de Segurança Nacional. In: FREITAS, M. C. (Org.). História social da infância no Brasil. São Paulo: Cortez, 1997. p.137-157.

Organizações multilaterais, Estado e políticas de educação infantil. Cadernos de Pesquisa, São Paulo, n. 115, p. 25-63, mar. 2002.

; ARTES, A. O rural e o urbano na oferta de educação para crianças até 6 anos. In: BARBOSA, Maria Carmen S. et al. (coord.). Oferta e demanda de educação infantil no campo. Porto Alegre: Evangraf, 2012.

SANTOS, M. M. R. de. A educação pré-escolar: um desafio a vencer. Em Aberto, MEC/INEP, Brasília, v. 1, n. 4, p. 8-13, mar. 1982.

SANTOS, W. G. Cidadania e justiça. Rio de Janeiro: Campus, 1979.

SARAIVA, T. Pré-escolar: urgência ou modismo. Em Aberto, MEC/INEP, Brasília, v. 1, n. 4, p. 1-7, mar. 1982.

SIROTA, R. Emergência de uma sociologia da infância: evolução do objeto e do olhar. Cadernos de Pesquisa, São Paulo, n. 112, p. 7-31, mar. 2001.

SOUSA, C. P. de. Saúde, educação e trabalho de crianças e jovens: a política social de Getúlio Vargas. In: GOMES, A. de C. (org.). Capanema: o ministro e seu ministério. Rio de Janeiro: FGV, 2000. p. 221-249.

SOUZA, P. N. P. Pré-escola: uma nova fronteira educacional. São Paulo: Pioneira, 1979.

VIEIRA, L. M. F. Creches no Brasil: de mal necessário a lugar de compensar carências; rumo à construção de um projeto educativo. 1986. Dissertação (Mestrado em Educação). Faculdade de Educação, Universidade Federal de Minas Gerais, Belo Horizonte, 1986.

Olhar de professor, Ponta Grossa, 16(1): 49-74, 2013. Disponível em <http://www.uepg.br/olhardeprofessor> 
Mal necessário: creches no Departamento Nacional da Criança (1940-1970). Cadernos de Pesquisa, São Paulo, n. 67, p. 3-16, nov. 1988.

Education de la petite enfance dans la législation éducationnelle brésilienne du XXème siècle: une approche historique de l'état du Minas Gerais (19082000). 2006. Tese (Doutorado em Ciências da Educação). Université René-Descartes, Paris V, Paris, 2006.

VILANOVA, L. K. P Programa Primeira Escola da Prefeitura de Belo Horizonte: uma análise dos critérios de acesso às Unidades Municipais de Educação Infantil. 2010. Dissertação (Mestrado em Educação). Faculdade de Educação, Universidade Federal de Minas Gerais, Belo Horizonte, 2010.

Legislação da educação e outros documentos nacionais oficiais

ALMEIDA JÚNIOR, A. Relatório Geral da Comissão. Revista Brasileira de Estudos Pedagógicos, Rio de Janeiro, v. 13, n. 36, p. 48-109, mai./ago. 1949.

BRASIL. Decreto-lei ${ }^{0} 8.529$, de 2 de janeiro de 1946, Lei Orgânica do Ensino Primário. INFORMATIVO MAI do Ensino do Estado de Minas Gerais, n. 209, 1993.

. Decreto-lei ${ }^{\circ} 8.530$, de 2 de janeiro de 1946, Lei Orgânica do Ensino Normal. INFORMATIVO MAI do Ensino do Estado de Minas Gerais, n. 209, 1993.

. Lei n. 4.024, de 20 de dezembro de 1961. Fixa as diretrizes e bases da educação nacional. INFORMATIVO MAI do Ensino do Estado de Minas Gerais, n. 209, 1993.

Lei n. 5.692, de 11 de agosto de 1971. Fixa as diretrizes e bases para o ensino de $1^{\circ}$ e $2^{\circ}$ graus, e dá outras providências.
INFORMATIVO MAI do Ensino do Estado de Minas Gerais, n. 209, 1993.

Constituição (1988). Constituição da República Federativa do Brasil. Brasília: Senado Federal, Centro Gráfico, 1988.

Lei $n^{0} 9.394$, de 20 de dezembro de 1996. Estabelece as diretrizes e bases da educação nacional. Diário Oficial da União, Brasília, DF, 23 dez. 1996.

Conselho Federal de Educação. Parecer CE $1^{\circ}$ e $2^{\circ}$ graus $n^{\circ} 2.018 / 74$ sobre Indicação $n^{\circ}$ 45: educação do pré-escolar. Aprovado em 5 de julho de 1974. Documenta, Brasília, v. 13, n. 164, p. 36-40, jul. 1974.

Indicação ${ }^{0} 45$. Documenta, Brasília, v. 13, n. 164, p. 40-44, jul. 1974.

Parecer CE $1^{\circ}$ e $2^{\circ}$ graus n ${ }^{\circ} 1.600 / 75$ sobre habilitação a nível de $2^{\circ}$ grau para 0 magistério do pré-escolar. Aprovado em 9 de maio de 1975. Documenta, Brasília, v. 14, n. 174, p. 67-73, mai. 1975.

Parecer CE $1^{\circ}$ e $2^{\circ}$ graus n ${ }^{\circ} 2.285 / 74$ sobre Projeto de lei ${ }^{\circ}$ 2029/74: dispõe sobre a educação pré-escolar. Aprovado em 7 de agosto de 1974. Documenta, Brasília, v. 13, n. 165, p. 379-381, ago. 1974.

Parecer CAPLAN n ${ }^{\circ}$ 1.112/80 sobre Indicação $n^{\circ}$ 8/79: Antecipação de escolarização no $1^{\circ}$ grau. Aprovado em 2 de outubro de 1980. Documenta, Brasília, n. 239, p. 1327, out. 1980.

Parecer CE $1^{\circ}$ e $2^{\circ}$ graus $n^{\circ} 792 / 80$ sobre Indicação $n^{\circ}$ 8/79: 0 ingresso no ensino de $1^{\circ}$ grau. Aprovado em 10 de julho de 1980. Documenta, Brasília, n. 236, p. 146155, jul. 1980.

Parecer CE $1^{\circ}$ e $2^{\circ}$ graus $n^{\circ} 2.521 / 75$ sobre Interpretação do art. $19, \S 1^{\circ}$, da Lei ${ }^{\circ}$ 5.692/71: programas antecipatórios da esco- 
larização regular. Aprovado em 2 de julho de 1976. Documenta, Brasília, v. 14, n. 176, p. 17-20, jul. 1975.

. Estudos especiais decorrentes do Aviso Ministerial no 288/81: Implantação de um sistema público de educação pré-escolar. Documenta, Brasília, n. 246, p. 22-32, maio 1981.

. IBGE. Síntese de indicadores sociais 2011. Rio de Janeiro: IBGE, Diretoria de Pesquisas, 2011. Disponível em http:// www.ibge.gov.br. Acesso em 15 setembro 2013.

Resultados gerais da amostra Censo Demográfico 2010. Disponível em http://www.ibge.gov.br. Acesso em 15 setembro 2013.

. MEC/INEP. Sinopse estatística da educação básica: 2012. Brasília: Instituto Nacional de Estudos e Pesquisas Educacionais, 2012. Disponível em http://www.inep. gov.br. Acesso em 15 setembro 2013.

MARIANI, C. Exposição de motivos e projeto de lei que acompanha a exposição de motivos. Revista Brasileira de Estudos Pedagógicos, Rio de Janeiro, v. 13, n. 36, p. 2-47, mai./ago. 1949.

PLANO de Educação Nacional: projeto de 1937. Revista Brasileira de Estudos Pedagógicos, Rio de Janeiro, v. 13, n. 36, p. 210 320, mai./ago. 1949.

RELATÓRIO do grupo de trabalho para a reforma do ensino de $1^{\circ}$ e $2^{\circ}$ graus. Revista Brasileira de Estudos Pedagógicos, Rio de Janeiro, v. 56, n. 123, p. 130-168, jul./set. 1971.

Legislação educacional de Minas Gerais

ESTADO DE MINAS GERAIS. Collecção das Leis e Decretos do Estado de Minas
Geraes - 1911. Bello Horizonte, Imprensa Official do Estado de Minas Geraes, 1911. p. 165. Decreto $\mathrm{n}^{\circ}$ 3.191, de 9 de junho de 1911. Approva o Regulamento Geral da Instrucção do Estado.

Collecção das Leis e Decretos do Estado de Minas Geraes - 1924, Bello Horizonte, 1925: Decreto $n^{\circ}$ 6.655, de 19 de agosto de 1924 - Regulamento do Ensino Primário; Lei $n^{\circ}$ 864, de 19 de setembro de 1924 - Approva o Regulamento do Ensino Primário.

Collecção das Leis e Decretos do Estado de Minas Geraes em 1927. Vol. II. Bello Horizonte, Imprensa Official do Estado de Minas Geraes, 1928. p. 1005: Decreto $\mathrm{n}^{\circ}$ 7.970-A, de 15 de outubro de 1927 - Approva o Regulamento do Ensino Primário.

Coleção dos Decretos de 1950. Belo Horizonte, Imprensa Oficial, 1958: Decreto ${ }^{\circ} 3.508$, de 21 de dezembro de 1950. Consolida as leis e decretos do ensino primário e contém outras disposições.

Decreto $\mathrm{n}^{\circ} 6.583$, de 17 de maio de 1962. Aprova o Planejamento dos Serviços Educacionais do Estado. Diário Oficial, v. 70, n 111, 1962. 19 de maio de 1962. p.01.

Resolução SEE $n^{\circ}$ 51, de 15 de janeiro de 1971. Trata da Administração Escolar do Estado. Diário Oficial, v. 79, n. 12, 1971. 19 de janeiro de 1971. p.07.

INFORMATIVO MAI DE ENSINO DO ESTADO DE MINAS GERAIS, Belo Horizonte, n.1, jan. 1974. Resolução SEE n 318/73, de 13 de dezembro de 1973. Estabelece normas e critérios que orientam a organização do Ensino Pré-Primário e de $1^{\circ} \mathrm{Grau}$, do Sistema Estadual e dá outras providências.

Belo Horizonte, n.14, fev. 1975. Resolução SEE n ${ }^{\circ} 1.106$, de 10 de dezembro de 1974. Estabelece normas e critérios que 
orientam a organização do Ensino Pré-Escolar e de $1^{\circ}$ Grau, da Rede Pública Estadual para 1975 e dá outras providências.

Belo Horizonte, n. 2, fev. 1976. Resolução SEE $n^{\circ}$ 1.728, de 9 de janeiro de 1976. Estabelece normas e critérios para o funcionamento do Ensino Pré-Escolar e para o Ensino de $1^{\circ}$ e $2^{\circ}$ Graus, da Rede Pública Estadual em 1976.

Belo Horizonte, n. 14, fev. 1977. Resolução SEE $n^{\circ}$ 2.155/77, de 7 de janeiro de 1977. Regulamenta o Ensino de $1^{\circ}$ e $2^{\circ}$ graus e a Educação Pré-Escolar na Rede Pública Estadual em 1977.

Belo Horizonte, n. 37, jan. 1979. Resolução SEE n ${ }^{\circ} 2.758 / 78$, de 13 de dezembro de 1978. Fixa normas de organização e funcionamento do ensino na rede de escolas estaduais.

Belo Horizonte, n. 192, jan. 1992. Resolução SEE n ${ }^{\circ} 6.906 / 92$, de 17 de janeiro de 1992. Dispõe sobre a organização e o funcionamento do ensino nas unidades estaduais de ensino.

Belo Horizonte, n. 200, ago. 1992. Resolução SEE n ${ }^{\circ} 7.012$, de 28 de junho de 1992. Dispõe sobre a expansão e reorganização do espaço escolar da rede estadual de ensino.

Belo Horizonte, n. 203-204, nov./ dez. 1992. Resolução SEE n ${ }^{0} 7.020 / 92$, de 17 de novembro de 1992. Dispõe sobre a organização e o funcionamento do ensino nas escolas estaduais.

Belo Horizonte, n. 212, ago. 1993. Resolução SEE ${ }^{\circ}$ 7.146/93, de 2 de junho de 1993. Dispõe sobre a expansão e reorganização do atendimento escolar na rede estadual de ensino.
Belo Horizonte, n. 215-216, nov./ dez. 1993. Resolução SEE $n^{0} 7.167 / 93$, de 24 de novembro de 1993. Dispõe sobre a organização e o funcionamento do ensino nas escolas estaduais.

Belo Horizonte, n. 218, fev. 1994. Resolução SEE no 7.174/94, de 18 de janeiro de 1994. Dispõe sobre a organização e o funcionamento do ensino nas escolas estaduais.

Belo Horizonte, n. 224, ago. 1994. Resolução SEE no 7.521/94, de 5 de julho de 1994. Dispõe sobre a expansão e reorganização do atendimento escolar na rede estadual de ensino.

Belo Horizonte, n. 241, jan. 1996. Resolução $\mathrm{n}^{\circ} 7.762$, de 19 de dezembro de 1995. Dispõe sobre a organização e o funcionamento do ensino nas escolas estaduais e dá outras providências.

Belo Horizonte, n. 287-288, nov.-dez. 1999. Resolução n. 158, de 3 de novembro de 1999. Dispõe sobre a expansão e reorganização do atendimento escolar na rede estadual de ensino e dá outras providências.
Enviado em: 20/06/2013

Aceito em: 18/07/2013 